九州大学学術情報リポジトリ

Kyushu University Institutional Repository

\title{
Pathogenicity of the Tn5 Inserted Mutant Strains of Pseudomonas glumae
}

Koga, Kazuharu

Laboratory of Plant Pathology, Faculty of Agriculture, Kyushu University

Furuya, Naruto

Laboratory of Plant Pathology, Faculty of Agriculture, Kyushu University

Wang, Zhiwe i

Laboratory of Plant Pathology, Faculty of Agriculture, Kyushu University

Wakimoto, Satoshi

Laboratory of Plant Pathology, Faculty of Agriculture, Kyushu University

他

https://doi.org/10.5109/24029

出版情報：九州大学大学院農学研究院紀要. 37 (3/4)，pp.359-369，1993-03. Kyushu University バージョン：

権利関係 : 


\title{
Pathogenicity of the Tn5 Inserted Mutant Strains of Pseudomonas glumae
}

\author{
Kazuharu Koga*, Naruto Furuya, Z hiwei W ang, \\ Satoshi Wakimoto'* and Nobuaki Matsuyama
}

Laboratory of Plant Pathology, Faculty of Agriculture, Kyushu University 46-01, Fukuoka 812, Japan

(Received December 28, 1992)

\begin{abstract}
Tn5 was inserted into the genome of Pseudomonas glumae, the plant pathogenic bacterium causing grain rot and seedling rot of rice, by conjugation with an Escherichiacoli strain carrying pJB4JI, the plasmid vector for Tn5. Kanamycin resistant transconjugants appeared at the frequency of $2.73 \times 10^{-5}$ per recipient. Of $250 \mathrm{Tn} 5$ mutant strains obtained, 3 strains completely lost their pathogenicity to rice seedlings and 28 strains were attenuated in virulence. The inserted Tn5 element was detected in the chromosome of the avirulent transconjugants by Southern blot analysis. Avirulent transconjugants multiplied similarly to the virulent original strain in media, while the virulent strain multiplied to reach about 10 times higher level as compared to the avirulent transconjugants on/in the grains of the inoculated seedlings. The original strain could decompose all kinds of the four substrates, pectin, pectic acid, carboxymethylcellulose (CMC) and casein, while most of the avirulent and attenuated strains could not decompose some of them. These results suggest that the degrading enzymes are playing some important roles in the expression of pathogenicity.
\end{abstract}

\section{INTRODUCTION}

Pseudomonas glumae Kurita and Tabei was first reported as the causal bacterium of the grain rot disease of rice (Tominaga, 1971; Goto et al., 1987). This disease was known to occur not only in Japan but also some other rice growing asian countries. In 1976, Uematsu et al. reported that this bacterium caused rice seedling rot in the nursery boxes under the controlled conditions of high humidity and high temperature (Uematsu et al., 1976a and 1976b). The symptoms of this disease are characterized by rotting of rice seedlings and growth inhibition accompanied with chlorosis or necrosis on the leaves or leaf sheaths.

In plant pathogenic bacteria, the factor(s) such as phytotoxin, plant cell wall degrading enzymes, extracellular polysaccharide and lipopolysaccharide produced by bacteria are known to be involved in the mechanisms of the expression of symptoms (Braun, 1955; Collmer and Keen, 1986; Ferguson and Johnston, 1980; Morris et al., 1977 and Stack et al., 1980).

Recent advances in the technology of DNA recombination have accelerated

* Present address: Leaf Tobacco Research Laboratory, Japan Tobacco Inc., Tochigi 323, Japan.

** Present address: Tokyo University of Agriculture, Tokyo 156, Japan. 
genetic analyses of the mechanisms of pathogenicity expression in some plant pathogenic bacteria. An important and versatile tool in this approach is the transposon, which is randomly transposable into bacterial DNA at single-site inducing nonleaky polar mutations with a specific phenotype such as drug resistance. Transposon mutagenesis greatly facilitates the cloning of specific genes or gene regions of chromosome (De Bruijn and Lupski, 1984).

The mechanism of the pathogenicity of $P$. glumae to rice seedlings has not been clarified. The purpose of this study is obtaining induced mutant strains which lost pathogenicity by insertion of the transposon Tn5 into chromosomal DNA of P. gl umae to clarify the mechanism of pathogenicity to rice seedlings.

\section{MATERIALS AND METHODS}

\section{Bacterial strains and plasmid}

A virulent mutant of Pseudomonas gl umae Ml, which was induced from P. glumae Kyu82-34-2 strain by UV irradiation, and Escherichia coli HB101 (Boyer and Roulland -Dussoix, 1969), which is bearing plasmid pJB4JI (Beringer et al., 1978) were used in this study.

\section{Media and growth condition}

The original strain Ml of $\mathbf{P}$. glumae was grown on YPA plate (yeast extract $5 \mathrm{~g}$, peptone $10 \mathrm{~g}, \mathrm{NaCl} 5 \mathrm{~g}$, agar $15 \mathrm{~g}$ per 1 liter of distilled water, $\mathrm{pH} 7.0$ ) at $30^{\circ} \mathrm{C}$. E. coli was grown on LB plate (Sambrook et al., 1989) (bacto-trypton $10 \mathrm{~g}$, yeast extract $5 \mathrm{~g}$, $\mathrm{NaCl} 10 \mathrm{~g}$ per 1 liter of distilled water, $\mathrm{pH} 7.0$ ) containing $50 \mathrm{ppm}$ of kanamycin and $100 \mathrm{ppm}$ of streptomycin at $37^{\circ} \mathrm{C}$. Tn5-inserted transconjugants were grown at $30^{\circ} \mathrm{C}$ on YPA plate containing kanamycin and streptomycin at the same concentration. Minimal medium $\left(\mathrm{K}_{2} \mathrm{HPO}_{4} 7 \mathrm{~g}, \mathrm{KH}_{2} \mathrm{PO}_{4} 3 \mathrm{~g},\left(\mathrm{NH}_{4}\right)_{2} \mathrm{SO}_{4} 1 \mathrm{~g}, \mathrm{MgSO}_{4} \cdot 7 \mathrm{H}_{2} \mathrm{O} 0.1 \mathrm{~g}\right.$, dextrose $5 \mathrm{~g}$, agar $15 \mathrm{~g}$ per 1 liter of distilled water) containing kanamycin $50 \mathrm{ppm}$ and streptomycin $100 \mathrm{ppm}$ was used to select transconjugants. To grow inocula, YPDA slant (yeast extract $3 \mathrm{~g}$, peptone $0.6 \mathrm{~g}$, dextrose $3 \mathrm{~g}$, agar $15 \mathrm{~g}$ per 1 liter of distilled water, $\mathrm{pH}$ 7.2) was used.

\section{Tn5 mutagenesis}

The donor strain, E. coli HB101, carrying the suicide plasmid pJB4JI::Tn5 was grown overnight in $5 \mathrm{ml}$ of LB broth. The recipient strain, P. glumae Ml, was grown in $5 \mathrm{ml}$ of YP broth for $48 \mathrm{hrs}$. The donor and recipient cells were mixed in sterilized tube (donor cells : recipient cells $=5: 1$ ), directly dropped on YPA plate and incubated at $30^{\circ} \mathrm{C}$ for $24 \mathrm{hrs}$. The cells were plated on the minimal medium containing kanamycin and streptomycin to select Tn5-inserted transconjugants. This procedure was practiced twice. The transconjugants were identified as P. glumae by serological reaction with anti-P. glumae serum preserved in the Laboratory of Plant Pathology, Faculty of Agriculture, Kyushu University (Wakimoto et al., 1987).

\section{Pathogenicity test}

Transconjugants were cultured on YPDA slant at $30^{\circ} \mathrm{C}$ for $48 \mathrm{hrs}$ and suspended into sterilized distilled water (ca. $10^{9} \mathrm{cfu} / \mathrm{ml}$ ). The rice grains Oryza sativa L. cv. 
Asominori, after removing their husks, were disinfected by soaking in $70 \%$ ethanol and sodium hypochlorite solution (3\% active chlorine). The disinfected grains were washed in sterilized distilled water and sown on $0.5 \%$ water agar in test tube ( 2 grain/ tube) and inoculated with $0.2 \mathrm{ml}$ of bacterial suspension. The virulence of the bacteria was evaluated at 10th day after inoculation.

\section{Preparation of DNA}

Genomic DNA was extracted from the cells of $P$. glumae cultured in minimal medium by the modified method of Silhavy et al. (1987). Extracted DNA was stored in TE buffer (Sambrook et al., 1989) at $4^{\circ} \mathrm{C}$. Plasmid pJB4JI DNA was extracted from E. coli by the method of Maniatis et al. (1989). After restriction with Hind111 (Boehringer Mannheim), the plasmid DNA was separated by $0.7 \%$ agarose gel electrophoresis and purified Tn5 fragment by Gene clean ${ }^{\mathrm{TM}}$ II (Funakoshi Medical Inc.) to use as a probe in Southern blot analysis.

\section{Southern blot hybridizations}

Genomic DNA fragments digested with EcoRI (Boehringer Mannheim) were separated by $1 \%$ agarose gel electrophoresis in Tris-acetate buffer (Sato et al., 1989) and transferred to Hybond ${ }^{\mathrm{TM}}-\mathrm{NT}$ (Amersham Inc.). For DNA labelling and DNA hybridization, ECL gene detection system (Amersham Inc.) was used according to the manufacturer's specification.

\section{Pigment productivity}

The pigment productivity of P. glumae on YPDA slant and in minimal medium was tested. The YPDA slant inoculated with the bacteria was incubated at $30^{\circ} \mathrm{C}$ and the minimal medium inoculated was shaken at the same temperature. The pigment productivity was observed at 48th $\mathrm{hr}$ of incubation with naked eye.

\section{Multiplication of $P$.glumae in media and on/in rice grains}

The multiplication of $P$. glumae was tested in sterilized distilled water, YP broth and minimal medium. The bacteria cultured on YPDA slant at $30^{\circ} \mathrm{C}$ for $48 \mathrm{hrs}$ were suspended in sterilized distilled water and inoculated into sterilized distilled water at the initial concentration of ca. $10^{5} \mathrm{cfu} / \mathrm{ml}$, and YP broth and minimal medium at the initial concentration of ca. $10^{7} \mathrm{cfu} / \mathrm{ml}$. After inoculation, the inoculated sterilized distilled water was incubated under still culture condition at $30^{\circ} \mathrm{C}$, and the YP broth and minimal medium were shaken at the same temperature. Water agar in test tube was used to grow rice seedlings to be inoculated. The bacterial cells cultured on YPDA slant at $30^{\circ} \mathrm{C}$ were suspended in sterilized distilled water. Each $10 \mathrm{ml}$ of water agar (agar conc. 0.5\%) supplemented with bacterial suspension at the concentration of ca. $10^{7} \mathrm{cfu} / \mathrm{ml}$ was divided into test tubes. The rice grains were disinfected by soaking in $70 \%$ ethanol and sodium hypochlorite solution (3\% active chlorine) and sown on the water agar in test tubes. The rice seedlings were periodically taken out, leaves and roots were discarded, and grains were homogenized and suspended in $5 \mathrm{ml}$ of sterilized distilled water. The suspension was plated on the minimal medium containing antibiotics to count viable $P$. glumae cells. 


\section{Activity of bacterial enzymes related to degrading plant cell wall}

To test the enzyme activities of the transconjugants degrading cell-wall, pectin, pectic acid (Wako Pure Chem. Indust. LTD.), carboxymethylcellulose (CMC), casein (Kyushu Katayama Chem. Inc.) were used as substrates. The bacterial strains cultured in $5 \mathrm{ml}$ of $\mathrm{YP}$ broth at $30^{\circ} \mathrm{C}$ for $48 \mathrm{hrs}$ were dropped on the plate of the media containing substrate $(10 \mu \mathrm{l})$ and incubated at $30^{\circ} \mathrm{C}$ for $24 \mathrm{hrs}$. The plates were then flooded with $1 \%(\mathrm{w} / \mathrm{v})$ aqueous solution of cetyltrimethylammonium bromide for detecting degradation of pectin (Jayasanker and Graham, 1970), pectic acid (Jayasanker and Graham, 1970) and casein (Tsuchiya et al., 1983). For testing degradation of CMC (Andre et al., 1984), 0.1\% (w/v) aqueous solution of congo red was flooded and blended with $1 \mathrm{M} \mathrm{NaCl}$. When the bacterial strains produced degrading enzymes, transparent zone was formed around the colony. The diameters of the transparent zone $(\mathrm{T})$ and the colony $(\mathrm{C})$ were measured. The enzyme activities were shown by $(\mathrm{T}$ $-\mathrm{C}) / \mathrm{C}$.

\section{RESULTS}

\section{Isolation of $\operatorname{Tn} 5$ mutants}

When the bacterial cultures of $P$. ghmae strain Ml and E.coli strain HB101 containing the plasmid pJB4JI were mixed, $P$. ghmae transpositional mutants, characterized by kanamycin resistance, arose at a frequency of approximately $2.73 \times 10^{-5}$ per recipient cells. Two hundred and fifty transconjugants were isolated. All transconjugants were confirmed to be $P$. ghmae by reaction with the anti-P. glumae serum which was previously cornfirmed to react specifically with P.glumae.

\section{Pathogenicity}

Of 250 transconjugants (tentatively TR numbered), 219 strains were as virulent as the original Ml strain, 28 strains were attenuated in some degree in virulence and 3 strains completely lost their pathogenicity.

Southern blot analysis of EcoRI-digested genomic DNA from mutants indicated the presence of Tn5 (Fig. 1).

\section{Pigment productivity}

On YPDA slant, all of the Tn5 inserted TR strains tested with only exception of TR5 strain produced yellowish-green pigment. However, only Ml strain produced the pigment in minimal medium (Table 1).

\section{Multiplication of $\mathbf{P}$. glumae in media and on/in rice grains}

In sterilized distilled water, both strains of Ml and TR5 multiplied showing the same pattern (Fig. 2). The bacteia also multiplied almost similarly both in YP broth and minimal medium, but later TR5 strain reached higher level than Ml strain (Fig. 3 and 4). On/in rice grains, the bacteria multiplied to reach plateau at the 4th day after inoculation. The population level of the virulent strain Ml was about 10 times higher than that of avirulent strain TR5 (Fig. 5). 


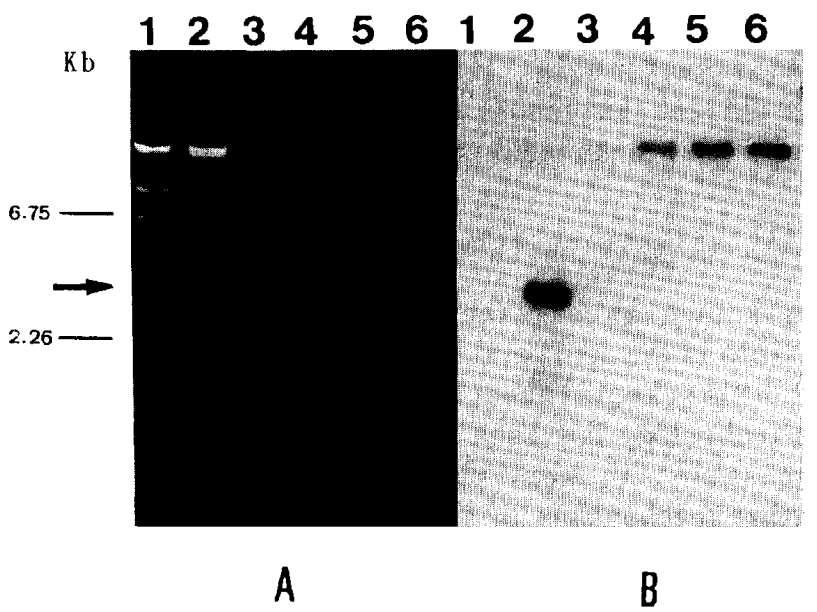

Fig. 1. Restriction enzyme and Southern blot analysis of genomic DNA isolated from Tn5 inserted mutants of P. glumae.

The genomic DNA fragments digested with EcoRI were separated by $1 \%$ agarose gel electrophoresis, transferred onto nyron membrane and hybridized with Tn5 fragment.

(A) Agarose gel electrophoresis (B) Southern hybridization. Lane 1: molecular weight marker lambda DNA digested with HindIII, lane 2: plasmid pJB4JI::Tn5 DNA digested with HindIII, lane 3-6: the chromosomal DNAs from P.glumae strains Ml and transconjugants (TR5, TR220, TR221) were digested with EcoRI. Arrow indicates $\mathrm{Tn} 5$ inserted fraction.

Table 1. Relationship between pigment productivity and pathogenicity in the randomly selected Tn5-inserted mutant strains of $P$. glumae.

\begin{tabular}{|c|c|c|c|}
\hline \multirow{2}{*}{ Strains } & \multicolumn{2}{|c|}{$\begin{array}{l}\text { Pigment productivity } \\
\text { of bacteria grown }\end{array}$} & \multirow{2}{*}{ Pathogenicity } \\
\hline & $\begin{array}{c}\text { on YPDA } \\
\text { medium }\end{array}$ & $\begin{array}{l}\text { in minimal } \\
\text { medium }\end{array}$ & \\
\hline M1 & + & + & +++ \\
\hline TR5 & - & - & \\
\hline TR220 & + & - & \\
\hline TR221 & + & - & \\
\hline TR8 & + & - & t \\
\hline TR50 & + & - & + \\
\hline TR179 & + & & + \\
\hline TR184 & + & & + \\
\hline TR131 & + & - & + \\
\hline TR129 & + & & ++ \\
\hline TR153 & + & & ++ \\
\hline TR199 & + & & ++ \\
\hline TR204 & + & - & ++ \\
\hline TR136 & + & - & +++ \\
\hline TR143 & + & & +++ \\
\hline
\end{tabular}




\section{Enzyme activities}

All strains decomposed pectin. However, some of the TR strains such as TR5 and TR50 strains did not decompose pectic acid, CMC and casein. TR8, TR131, TR184, TR220 and TR221 strains did not decompose only CMC (Table 2).

\section{DISCUSSION}

P. glumae is known as a pathogenic bacteria causing bacterial grain rot (Tominaga, 1971; Goto el al., 1987) and seedling rot of rice (Uematsu et al., 1976a and 1976b). However, little is known about the mechanisms of symptom expression by the bacterium. Gene technology has been widely applied to clarify the mechanisms of pathogenicity expression with many plant pathogenic bacteria (Kerr, 1987; Nester, 1984) and the rotting mechanisms of rice seedlings by P.glumae were studied by applying Tn5-insertion in this experiment.

Of 250 transconjugants obtained, $219(87.6 \%)$ were as virulent as wild strain, 28 (11. $2 \%$ ) were attenuated in virulence, and $3(1.2 \%)$ were avirulent. Thus, transconjugants were different in virulence. Salch et al. (1988) reported that the 2,686 kanamycin resistant strains were obtained by conjugation between E.coli WA803 (pGS9::Tn5) and P. syringae pv. tabaci. With regard to the pathogenicity of these mutant strains against tobacco leaves, 8 strains $(0.3 \%)$ showed no symptoms and 10 strains were

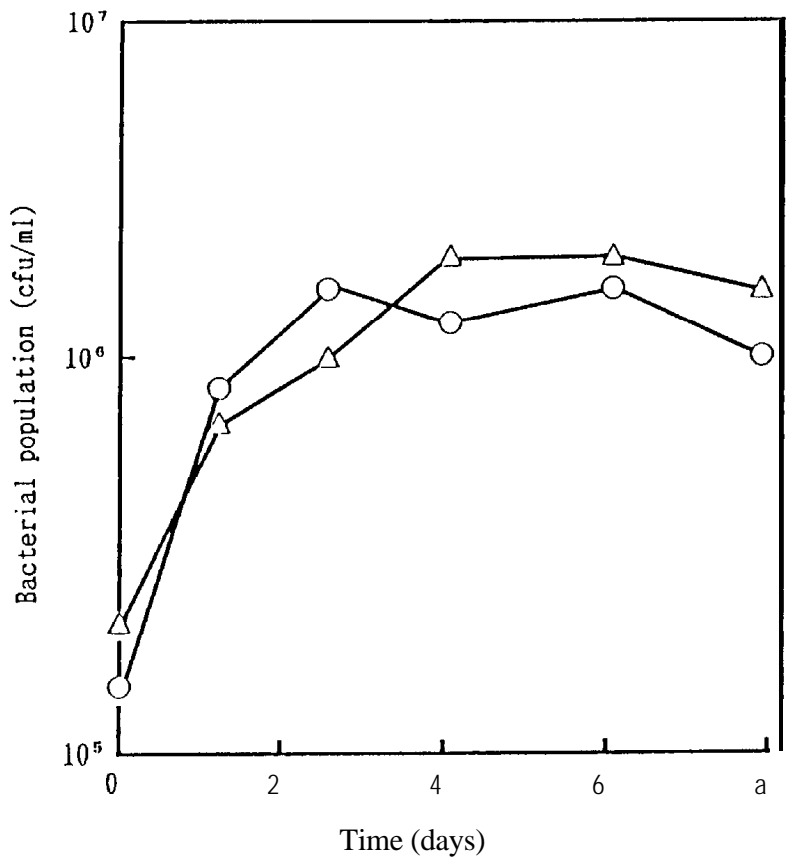

Fig. 2. Growth of $P$. glumae in sterilized distilled water at $30^{\circ} \mathrm{C}$.

$-\mathrm{O}-$ : strain M1 -A-: strain TR5 
attenuated (Salch and Shaw, 1988). The frequency of avirulent transconjugants in the case of P. glumae was much higher than in the case of $\mathbf{P}$. syringae pv. tabaci. In $\mathbf{P}$. solanacearum, wilt induction to host plants had been attributed in part to the production of slime which composed mostly of extracellular polysaccharide (EPS) (Husain and Kelman, 1958). However, virulent strain of P. solanacearum which lacks of EPS productivity was found in Tn5 inserted strains (Xu et al., 1990) and plant cell wall degrading enzyme was found to be related to pathogenicity (Roberts et al., 1988).

Our results suggest that many gene regions may be related to the symptom expression. However, a few gene regions which are critical for pathogenicity expression by P. glumae may exist, because 3 transconjugants completely lost their pathogenicity by Tn5 insertion.

The multiplication of the avirulent strain (P. glumae transconjugant TR5) was

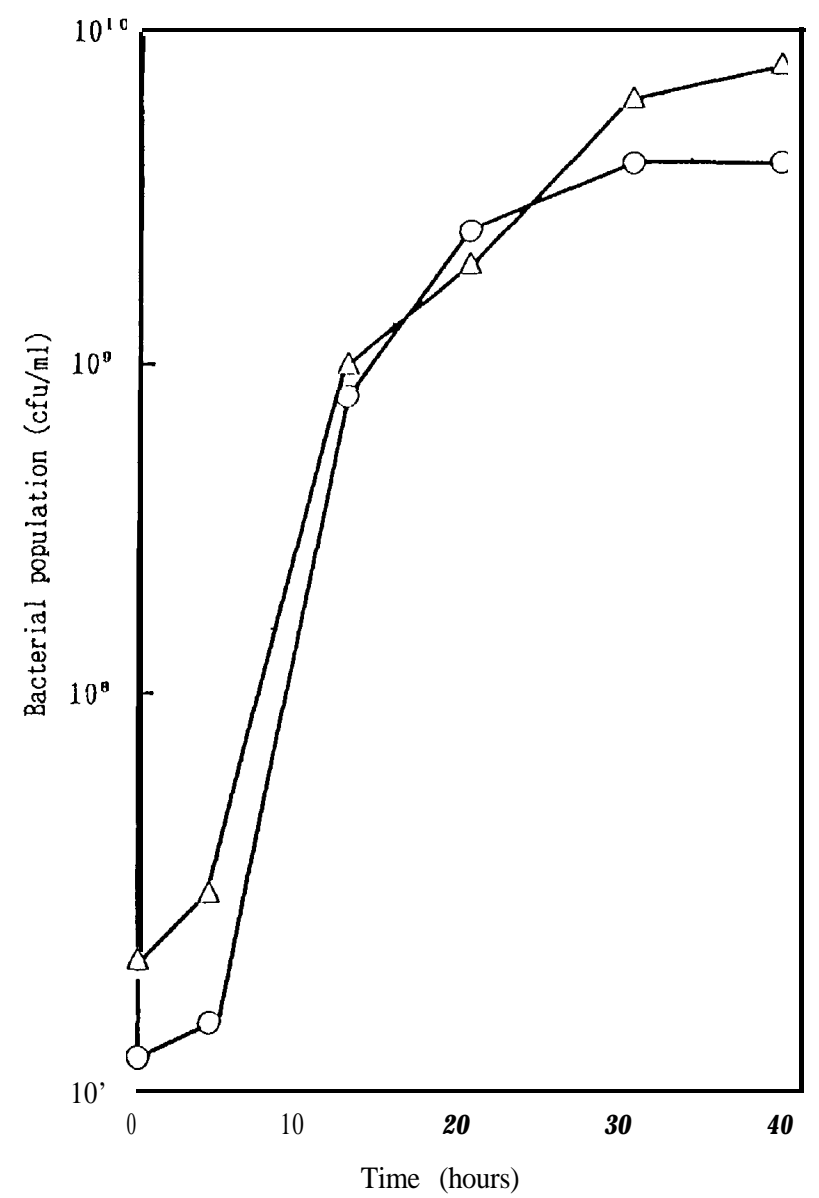

Fig. 3. Growth of $P$. glumae in YP broth under shaking condition at $30^{\circ} \mathrm{C}$.

Fig. 3. Growth of $P$. glumae in YP broth un
- : strain $\mathrm{Ml}-\triangle-$ strain TR5 
compared with that of the virulent strain (P.glumae Ml) in media and on/in the grains of rice seedlings. Both avirulent and virulent strains multiplied showing almost the same patterns in the media. On/in the grains, however, the virulent strain multiplied to reach the level about 10 times higher than that of the avirulent strain. The difference of both strains in virulence may be due to the difference in multiplication inside host tissues.

Multiplication of pathogenic bacteria in plant tissue is considered to be depended upon nutritients released from host cells to intercellular spaces. Therefore, the enzyme activities which were considered to be related to degrading plant cell-wall were examined to know their roles in pathogenicity. As a result, the highly virulent strains decomposed all of the four substrates, pectin, pectic acid, CMC and casein, while attenuated strains lost some of the degrading activities of pectic acid, CMC or

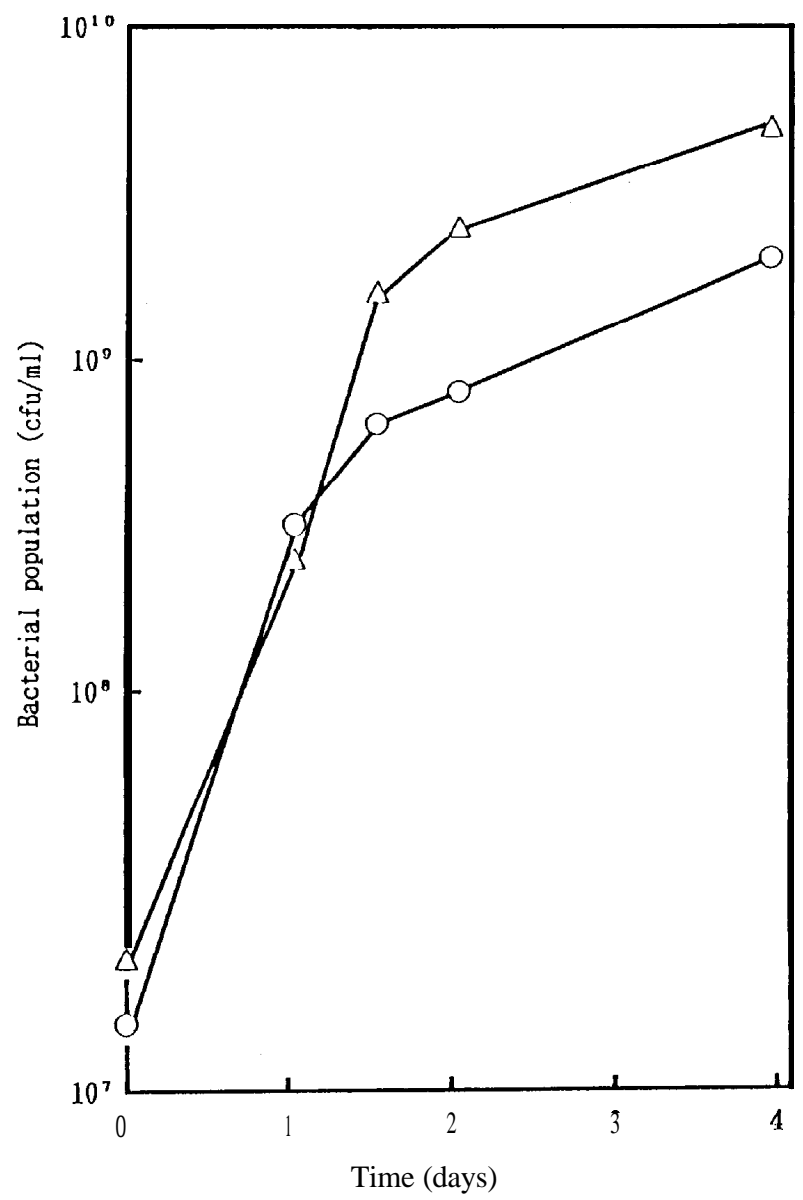

Fig. 4. Growth of P. glumae in minimal broth under shaking condition at $30^{\circ} \mathrm{C}$. - - : strain M1 -A-: strain TR5 
casein. These results suggest that the enzyme activities are playing some roles in the pathogenicity to rice seedlings. Recently, some phytotoxins were reported as a possible factor to cause rice seedling rot (Sato et al., 1989).

The productivity of phytotoxins from the Tn5 inserted mutants shoud be tested in future.

\section{ACKNOWLEDGEMENTS}

The authers wish to thank Dr. M. Sato, National Institute of Agro-Environmental Sciences for generously providing the plasmid containing Tn5 and also for his advice.

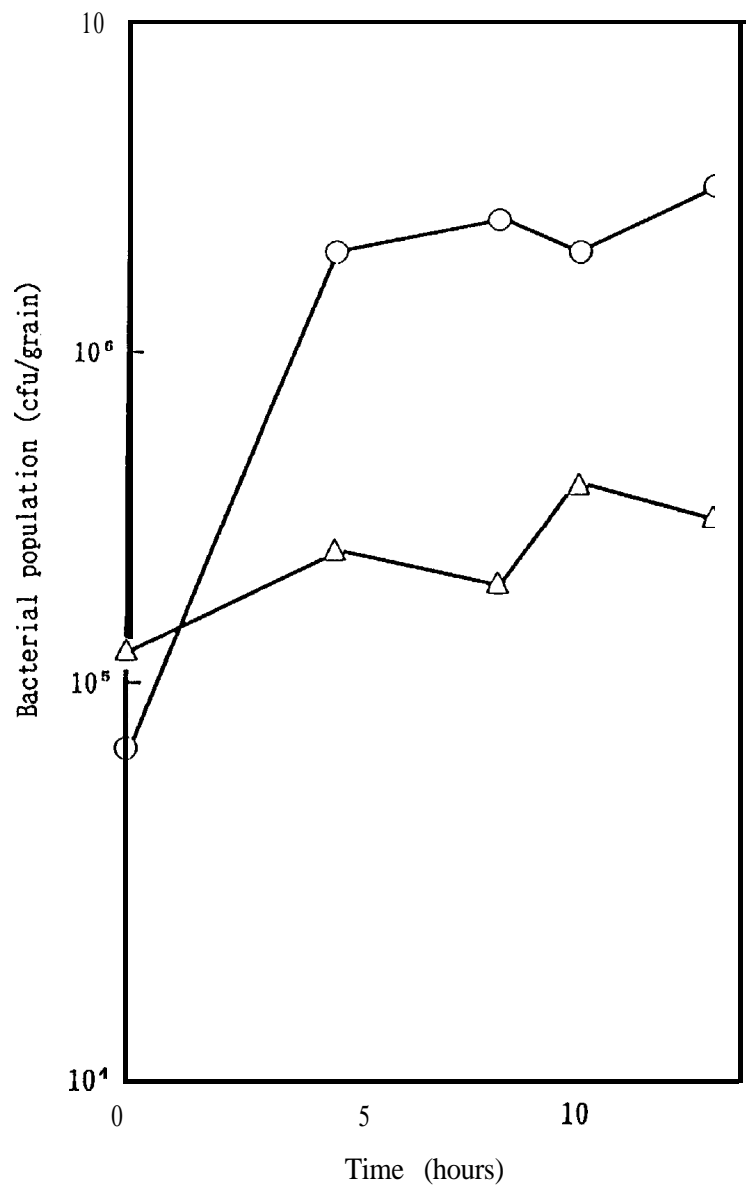

Fig. 5. Multiplication of P. glumae cells on/in the grains of rice seedlings, $-\mathrm{O}-$ : strain $\mathrm{Ml} \longrightarrow \triangle \longrightarrow$ : strain TR5 
Table 2 . Relationship between enzyme activities related to decompose host cell-wall and pathogenicity in the randomly selected Tn5-inserted mutant strains of P. glumae

\begin{tabular}{|c|c|c|c|c|c|}
\hline \multirow{2}{*}{ Strains } & \multicolumn{4}{|c|}{ Substrates } & \multirow{2}{*}{ Pathogenicity } \\
\hline & Pectin & Pectic acid & $\mathrm{CMC}$ & Casein & \\
\hline M1 & $1.57^{\prime \prime}$ & 0.59 & 0.67 & 1.02 & +++ \\
\hline TR5 & 1.32 & 0 & 0 & 0 & - \\
\hline TR220 & 1.06 & 0.34 & 0 & 0.61 & - \\
\hline TR221 & 1.03 & 0.40 & 0 & 0.77 & - \\
\hline TR8 & 1.32 & 0 & 0 & 1.02 & + \\
\hline TR50 & 0.66 & 0 & 0 & 0 & + \\
\hline TR179 & 1.67 & 0.56 & 0.67 & 0.72 & + \\
\hline TR184 & 0.95 & 0.37 & 0 & 0.45 & + \\
\hline TR131 & 1.90 & 0.75 & 0 & 0.81 & + \\
\hline TR129 & 1.20 & 0.63 & 0.42 & 0.69 & ++ \\
\hline TR153 & 1.53 & 0.40 & 0.31 & 0.95 & ++ \\
\hline TR199 & 1.45 & 0.60 & 0.63 & 0.79 & ++ \\
\hline TR204 & 1.29 & 0.50 & 0.50 & 0.79 & ++ \\
\hline TR136 & 1.64 & 0.50 & 0.50 & 0.79 & $+t+$ \\
\hline TR143 & 1.56 & 0.40 & 0.32 & 0.73 & +++ \\
\hline
\end{tabular}

a) $(\mathrm{T}-\mathrm{C}) / \mathrm{C}$ ratio, $\mathrm{T}$ : diameter of transparent zone, $\mathrm{C}$ : colony diameter

\section{REFERENCES}

Andre, T., J. Chambost, A. Kotoujansky, J. Cattaneo, Y. Bertheau, F. Barras, F. Gijsegem and A. Coleno 1984 Mutants of Erwinia chrysanthemi defective in secretion of pectinase and cellulase. J. Bacteriol., 160-3: 1199-1203

Beringer, J. E., J. L. Beynon, A. V. Buchnanan-Wollaston and A. W. B. Johonston 1978 Transfer of the drug-resistance transposon Tn5 to Rhizobium. Nature, 276: 633-634

Boyer, H. W. and D. Roulland-Dussoix 1968 A complementation analysis of the restriction and modification of DNA in Escherichiacoli. J. Nol. Biol., 41: 459-472

Braun, A, C. 1955 A study on the model of the wildfire toxin. Phytopathology, 45: 659-664

Collmer, A. and N. T. Keen 1986 The role of pectic enzymes in plant pathogenesis. Ann. Rev. Phytopathol., 24: 384-409

Crosthwaite, L. M. and S. J. Sheen 1979 Inhibition of ribrose 1,5-bisphosphate carboxlase by a toxin isolated from Pseudomonas tabaci. Phytopathology, 69: 376-379

De Bruijn, F. J. and J. R. Lupski 1984 The use of transposon Tn5 mutagenesis in the rapid generation of correlated physical and genetic maps of DNA segments cloned into multicopy plasmids. Gene, 27: 131-149

Ferguson, A. R. and J. S. Johnston 1980 Phaseolotoxin: chlorosis ornithine carbamoyltransferase in different plants. Physiol. Plant Pathol., 16: 269-275

Goto, T., K. Nishiyama and K. Ohata 1987 Bacteria causing grain rot of rice. Ann. Phytopath. Soc. Japan, 53: 141-149

Husain, A. and A. Kelman 1958 Relation of slime production to mechanism of wilting and pathogenicity of Pseudomonas solanacearum. Phytopathology, 48: 155-165

Jayasanker, N. P. and P. H. Graham 1970 An agar plate method for screening and numerating pectinolytic microorganisms. Can. J. Microbiol., 16: 1023

Kerr, A. 1987 The impact of molecular genetics on plant pathology. Ann. Rev. Phytopathol., 25: 87 $-110$ 
Kuchino, Y., H. Hirai and I. Sakurabayashi 1987 Blotting Method. Softscicnce Inc. Tokyo $32-38$ (in Japanese).

Morris, E. R., D. A. Reese, G. Young, M. D. Walkinshow and A. Darke 1977 Order-disorder transition for a bacterial polysaccharide in solution. A role for polysaccharide conformation in recognizing between Xanthomonas pathogen and its plant host. J. Mol. Biol., 110: 1-16

Nester, E. W., M. P. Gordon, R. M. Amasino and M. F. Yanofsky 1984 Crown gall: a molecular and physiological analysis. Ann. Rev. Plant Physiol., 35: 387-413

Roberts, D. P., T. P. Denny and M. A. Schell 1988 Cloning of the egl gene of Pseudomonas solanacearum and analysis of its role in phytopathogenicity. J. Bacteriol., 170: 1445-1451

Salch, Y. P. and P. D. Shaw 1988 Isolation and characterization of pathogenicity genes of Pseudomonas syringae pv. tabaci.J. Bacteriol., 170: 2584-2591

Sambrook, J., E. F. Fritsch and T. Maniatis 1989 Molecular Cloning. Cold Spring Harbor Laboratory Press.

Sato, A., Y. Koiso, S. Iwasaki, I. Matsuda and A. Shirata 1989 Toxins produced by Pseudomonas glumae. Ann. Phytopath. Soc. Japan, 55: 353-356

Stack, J. P., P. M. Mount, P. M. Berman and J. P. Hubbard 1980 Pectic enzyme complex from Erwinia carotovora: A model for degradation and assimilation of host pectic fraction. Phytopathology, 70: 267-272

Tominaga, T. 1971 Studies on the diseases of forage crops in Japan. Bull. Nat. Inst. Agr. Sci., Series C-25: 237-240

Tsuchiya, K., N. Matsuyama and S. Wakimoto 1983 Studies on the relationship between virulence and bacteriorogical properties in Enwinia carotovora subsp. carotovora. J. Fac. Agr. Kyushu Univ. 27: 197-207 (in Japanese).

Uematsu, T., D. Yoshimura, K. Nishiyama, T. Ibaragi and H. Fujii 1976a Occurrence of bacterial seedling rot in nursery flat, caused by grain rot bacterium Pseudomonas glumae. Ann. Phytopath. Soc. Japan, 42: 310-312 (in Japanese).

Uematsu, T., D. Yoshimura, K. Nishiyama, T. Ibaragi and H. Fujii 1976b Pathogenic bacterium causing seedling rot of rice. Ann. Phytopath. Soc. Japan, 42: 464-471 (in Japanese).

Wakimoto, S., M. Araki and K. Tsuchiya 1987 Serological specificity of Pseudomonas glumae, the pathogenic bacterium of grain rot disease of rice. Ann. Phytopath. Soc. Japan, 53: 150-158

Xu, P., M. Iwata, S. Leong and L. Sequeira 1990 Highly virulent strains of Pseudomonas solanacear. urn that are defective in extracellular-polysaccharide production. J. Bacteriol., 172: 3946-3951 